\title{
Synchronous Primary Cervical Cancer and Follicular Lymphoma- A Case Report
}

\author{
Angel Yordanov ${ }^{1 *}$, Martin Karamanliev², Dobromir Dimitrov ${ }^{3}$ and Tsvetomir Ivanov $^{3}$ \\ ${ }^{1}$ Clinic of Gynecologic Oncology, University Hospital "Dr.Georgi Stranski”-Pleven, Bulgaria \\ ${ }^{2}$ Medical University Pleven, Bulgaria \\ ${ }^{3}$ Department of Surgical Oncology, Medical University Pleven, Bulgaria
}

Submission: September 15, 2017; Published: September 21, 2017

*Corresponding author: Angel Yordanov, Clinic of Oncogynecology, University Hospital “Dr. Georgi Stranski”-Pleven, Bulgaria, Tel: +359887671520, Email: angel.jordanov@gmail.com

\section{Abstract}

Double synchronous primary cancers of gynecological cancers are a relatively common event. However, synchronous primary genital and extraginital cancers are a rare event. We report a case with synchronous primary cervical cancer and non-hodgin lymphoma-follicular lymphoma. Recently, a 43-year-old women presented with abnormal uterine bleeding was found to have a T1bpN1Mx cervical cancer and a inguinal lymphomegaly presentation of follicular lymphoma. We present this case with a brief review of references.

Keywords: Cervical cancer; Non-Hodgkin lymphoma; Follicular lymphoma; Synchronous cancer

Abbreviations: NHL: Non-Hodgin Lymphoma; D\&C: Dilatation and Curettage; RHT: Radical Hysterectomy; CD: Cluster of Differentiation; Tly: T-Lymphocyte; FDC: Folicullar Dendritic Cell

\section{Introduction}

Cervical cancer is the sixth most common cancer in Europe for females, and the 16th most common cancer overall, with around 58,400 new cases diagnosed in 2012 (4\% of female cases and $2 \%$ of the total) [1]. Non-Hodgkinlymphoma (NHL) is the 11 th most common cancer in Europe, with around 93,500 new cases diagnosed in 2012 (3\% of the total) [1]. Double synchronous primary cancers of gynecological cancers is a relatively common event. However, synchronous primary cervical cancer and NHL follicular lymphoma is a rare event.

\section{Case Reports}

A 43-year-old Caucasian female, para 2-0-0-2, with negative personal or family history of neoplasm was admitted to the Clinic of Gynecologic Oncology, University hospital “Dr. GeorgiStranski”, Pleven, Bulgaria, with history of abnormal uterine bleeding and dyspareunia for 2 months. Other past history and family history were unremarkable.

Gynecological examination was normal for her age. Her physical examination revealed blood pressure $120 / 80 \mathrm{mmHg}$, pulse rate $68 / \mathrm{min}$, respiratory rate $16 / \mathrm{min}$. In left inguinal region an $80 / 40 \mathrm{~mm}$ unpainful, mobile, pitting mass was palpated. The outer skin was intact.

Dilatation and curettage (D\&C) was performed, resulting in histological data for a non-keratizing squamous cell carcinoma. Due to clinical data for an early stage of the disease a decision forradical hysterectomy (RHT) with adnexectomy and total pelvic lymphectomy was taken, which was performed a month later. The histopathology showed keratizing squamous cell carcinoma G1 of the cervix and 1 metastatic lymph node from 20 examined. The tumor was classified as pT1bpN1Mx.

The patient was referred to Department of Surgical Oncology, University hospital "Dr. GeorgiStranski", Pleven, Bulgaria, for an inguinal lymph nodeexcison (Figure 1). The histopathology revealed lymph nodes with follicular architecture-large uniform follicles without germinal centers and polarization composed of centrocytes and single centroblasts. On immuno histochemical investigation, neoplastic follicles were $\mathrm{CD} 20(+)$; $\mathrm{CD} 10(+)$; Bcl2(+);Bcl6(+);Ki67 5-7\%; CD3(+) in TLy and CD23(+) in FDC; - Follicular lymphoma G1. A cervical, thoracic, abdominal and pelvic contrast-enhanced CT scan was performed which showed 
only an enlarged solitary left inguinal lymph node.The patient under went radiotherapy at the dose of $45 \mathrm{~Gy}$ for 5 weeks. The patient is alive, feeling well, with no physical data for progression of the disease at 6-month follow-up.

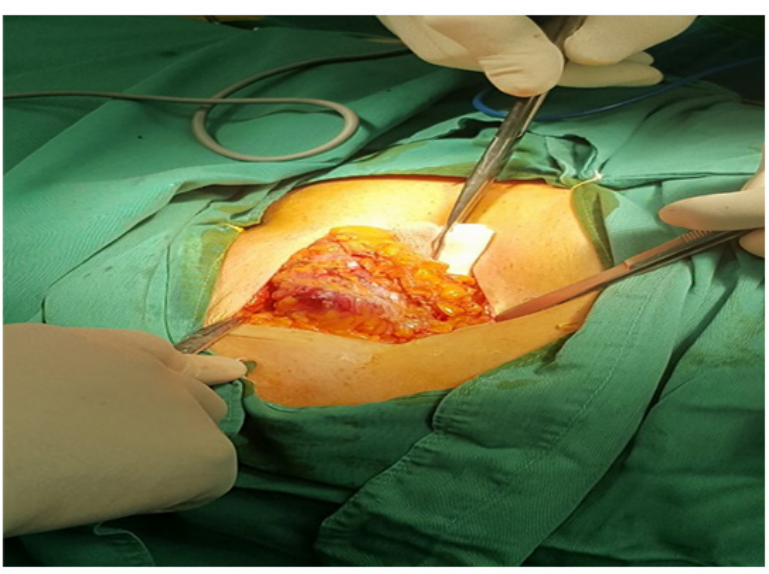

Figure 1: Left inguinal lymph nodes.

\section{Discussion}

In case of proven cervical cancer with inguinal lymphadenomegaly, the most common reason for the latter is cervical cancer metastasis. Thus, in our case the inguinal lymphadenomegaly was due to follicular lymphoma. Two or more tumors occurring in a patient simultaneously are defined as synchronous [2]. Eisner et al. [3] investigated 3863 patients with female genital malignancies and found that $0.7 \%$ of them were with synchronous primary genital cancers and no cases of synchronous genital and extragenital cancers. To the best of our knowledge this is the first case report of a synchronous cervical cancer and follicular lymphoma. Synchronous primary cancers have much better survival rates than metastatic cases [3]. Zhang et al. [4] defined parametrial and obturator lymph nodes as level I lymph nodes in cervical cancer metastasis. Internal and external iliac lymph nodes can be considered as level II lymph

This work is licensed under Creative Commons Attribution 4.0 Licens DOI: 10.19080/JOJCS.2017.04.555635 nodes and the common iliac and inguinal lymph nodes as level III nodes. Nodal metastasis from cervical cancer most commonly occurs in the obturator nodes, internal iliac nodes, or external iliac nodes; in the absence of metastasis to these sites, metastasis to paraaortic and inguinal nodes are rare $[5,6]$.

\section{Conclusion}

In cancer patients a lymphadenomegaly can be a diagnosting problem. The complex clinical data should be taken into account and the possibility of synchronous processes should not be excluded.

\section{Acknowledgement}

The publication was funded by progect BG05M20P0012.009-0031-C01.

\section{References}

1. Ferlay J, Soerjomataram I, Ervik M, Dikshit R, Eser S, et al. (2013) GLOBOCAN 2012 v1.0, Cancer Incidence and Mortality Worldwide. In: Ferlay J, Soerjomataram I, Ervik M, Dikshit R, Eser S, et al. (eds.), International Agency for Research on Cancer. IARC CancerBase No. 11. Lyon, France.

2. Ree YS, Cho SH, Kim SR, Kim KT, Park MH, et al. (2003) Synchronous primary endometrial and ovarian cancer with three different histologic patterns: a case report. Int J Gynecol Cancer 13(5): 678-682.

3. Eisner RF, Nieberg RK, Berek JS (1989) Synchronous primary neoplasms of the female reproductive tract. Gynecol Oncol 33(3): 335339.

4. Zhang H, Sheng X, Zhong Y, Ma Z, Ma Y, et al. (2008) The rule of metastatic pelvic lymph node distribution in patients with early stage cervical carcinoma. Zhonghua Zhong Liu Za Zhi 30(6): 452-455.

5. Sakuragi N, Satoh C, Takeda N, Hareyama H, Takeda M, et al. (1999) Incidence and distribution pattern of pelvic and paraaortic lymphnode metastasis in patients withS tages IB, IIA, and IIB cervical carcinoma treated with radical hysterectomy. Cancer 85(7): 1547-1554.

6. Lee JM, Lee KB, Lee SK, Park CY (2007) Pattern of lymphnode metastasis and theoptimal extent of pelvic lymphadenectomy in FIGO stage IB cervical cancer. J Obstet Gynaecol Res 33(3): 288-293.

\begin{tabular}{l} 
Your next submission with Juniper Publishers \\
will reach you the below assets \\
- Quality Editorial service \\
- Swift Peer Review \\
- Reprints availability \\
- E-prints Service \\
- Manuscript Podcast for convenient understanding \\
- Global attainment for your research \\
- Manuscript accessibility in different formats \\
( Pdf, E-pub, Full Text, Audio) \\
- Unceasing customer service \\
Track the below URL for one-step submission \\
https://juniperpublishers.com/online-submission.php \\
\hline
\end{tabular}

